\title{
The origin and significance of the Delaney Dome Formation, Connemara, Ireland
}

\author{
AMY E. DRAUT ${ }^{1}$ \& PETER D. CLIFT ${ }^{2}$ \\ ${ }^{1}$ Massachusetts Institute of Technology/Woods Hole Oceanographic Institution Joint Program in Oceanography, \\ Woods Hole, MA 02543, USA (e-mail: adraut@whoi.edu) \\ ${ }^{2}$ Department of Geology and Geophysics, Woods Hole Oceanographic Institution, Woods Hole, MA 02543, USA
}

\begin{abstract}
Dalradian meta-sediments of the Laurentian margin and mafic intrusions thereof in SW Connemara, Ireland, tectonically overlie meta-rhyolites of the Delaney Dome Formation. The two units are separated by the Mannin Thrust. A new U-Pb age of $474.6 \pm 5.5$ Ma shows that the Delaney Dome Formation is a temporal equivalent of arc volcanic rocks preserved in the adjacent South Mayo Trough: the Tourmakeady Volcanic Group, erupted during the collision of an oceanic island arc with the Laurentian margin in the Grampian Orogeny. New rare earth and high field strength element data show that the Delaney Dome Formation and Tourmakeady Volcanic Group are chemically similar and arc-like in character. This suggests that the Delaney Dome Formation is an along-strike equivalent of the Tourmakeady Group, strike-slip faulted south of the South Mayo Trough during or after the Grampian Orogeny. Further correlation of these units with northern Appalachian rhyolites is also possible. The Delaney Dome Formation is an extrusive temporal equivalent of intrusions that penetrate the Connemara Dalradian. Thus, movement along the Mannin Thrust brought mid-crustal plutons and Dalradian country rocks tectonically above the extrusive volcanic sequence. The Mannin Thrust is identified as a major imbricating structure within a continental arc, but not a terrane boundary.
\end{abstract}

Keywords: Ireland, Grampian Orogeny, U-Pb, geochemistry, subduction, plate collision.

The Connemara region represents a classic exotic terrane within the western Irish Caledonides. This metamorphic terrane is located inside an arc-continent suture zone formed during incipient closure of the Iapetus Ocean in the early Ordovician Grampian Orogeny (c. 475-462 Ma). Lithologically, the Connemara block is usually correlated with the meta-sediments of the Dalradian Group of Scotland and North Mayo (e.g. Yardley 1976), making it part of the margin of the Laurentian continent. Its tectonic position south of (i.e., oceanward of) the South Mayo forearc terrane, implies that Connemara has been displaced along strike by transform faulting from an adjacent section of the Laurentian margin (Hutton 1987). The timing of this motion is typically considered to be Late Ordovician (c. 460 to $>443 \mathrm{Ma}$; Late Llanvirn to Caradoc) based on the age of the Derryveeny Conglomerate in South Mayo, which contains clasts of Connemara-type lithologies derived from the south (Graham et al. 1991). A separate exotic origin independent of Laurentia has remained a possibility to explain the location of the Connemara terrane (Bluck \& Dempster 1991). In this paper we examine the age and geochemical affinity of Connemara's Delaney Dome Formation and attempt to relocate it within the original geometry of the Grampian Orogeny. The purpose is to understand the original tectonic setting of the enigmatic Delaney Dome Formation and its development during the Grampian Orogeny, which has implications for the interpretation of similar arccontinent collision zones elsewhere.

The meta-sediments of the Connemara terrane, together with their North Mayo and Scottish equivalents, have been interpreted as passive margin sediments and intracratonic basin deposits of the Laurentian continent (e.g., Harris et al. 1994). These sediments underwent four deformation events $\left(D_{1-4}\right.$; e.g. Leake 1986) during which they were deformed and intruded by gabbro, diorite and granitic bodies during the
Early-Mid-Ordovician Grampian Orogeny (Friedrich et al. $1999 a, b)$. The Grampian Orogeny, equivalent to the Taconic of North America (Karabinos et al. 1998), is generally considered to be the result of a collision between the passive margin of Laurentia and an intra-oceanic island arc that formed within the Iapetus Ocean during the Late Cambrian (e.g. Ryan et al. 1980; Dewey \& Ryan 1990; McKerrow et al. 1991; van Staal et al. 1998). Although in many regions of the Appalachian-Caledonide orogen the Grampian/Taconic history has been overprinted by later phases of orogeny and deformation related to the Silurian final closure of Iapetus, the Ordovician history is well-preserved in western Ireland. Most notably a record of arc-continent collision is preserved in the South Mayo Trough area, adjacent to Connemara, allowing direct correlation between middle and upper crustal levels (exposed in the intrusions of Connemara and volcanics of South Mayo, respectively) during the Grampian Orogeny (e.g. Leake et al. 1983; Draut \& Clift 2001). The South Mayo Trough has been variously interpreted, but is now generally recognized as a forearc basin to the Ordovician Lough Nafooey Arc that collided with Laurentia during the Grampian Orogeny (e.g. Dewey \& Ryan 1990; Soper et al. 1999).

\section{The Delaney Dome}

The Connemara Dalradian (Fig. 1) is bounded to the north by high-angle strike-slip faults, now covered by Silurian and Carboniferous strata, that juxtapose this unit against the un-metamorphosed sediments and lavas of South Mayo. To the south, the Dalradian is intruded by the Devonian Galway Granite and is transgressed by Carboniferous sediments, obscuring its relations with other arc units or with the Avalonian 

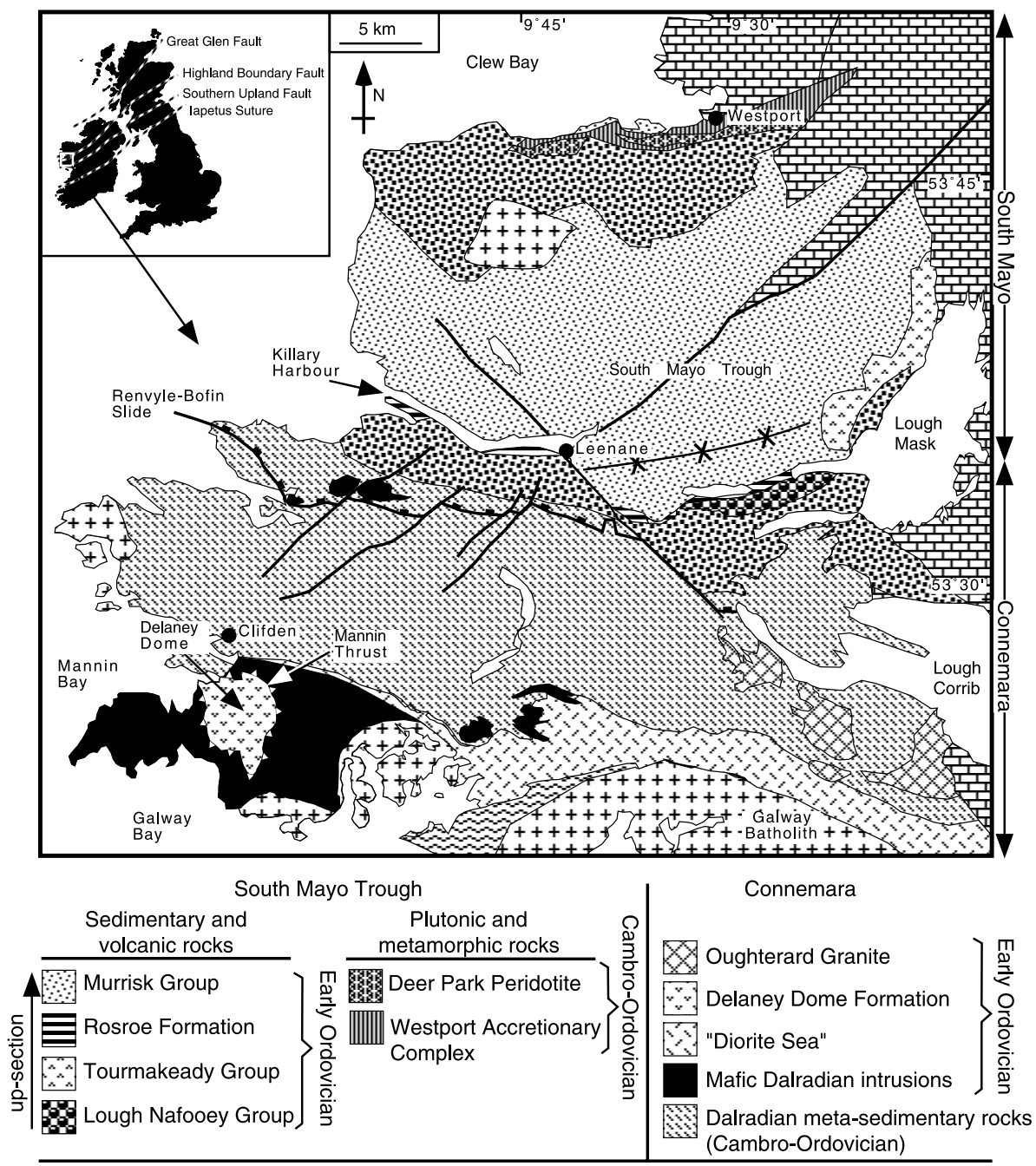

Post-Grampian

9ilurian $\begin{aligned} & ++ \\ & ++\end{aligned}$ Devonian granites ${ }^{2}$ Devonian-Carboniferous

Fig. 1. Simplified geologic map of the South Mayo and Connemara area, with an insert showing the location within the Iapetus Suture Zone in western Ireland. The terrane boundary between Connemara and the South Mayo Trough is obscured by Silurian and Carboniferous deposits. continental block that dominates the southern British Isles, south of Roundstone the Connemara Dalradian is seen in tectonic contact with mafic, apparently ophiolitic, rocks that comprise the top of the South Connemara Group (Ryan \& Dewey, 1991). In SW Connemara the Dalradian is seen to be in low-angle thrusted contact with the underlying Delaney Dome Formation. The tectonic contact is called the Mannin Thrust. The Delaney Dome is a structural high that forms a tectonic window through a thrust sheet of Dalradian amphibolite into deformed rhyolites and ignimbrites (Fig. 1). The contact between mylonitic Delaney Dome rocks and the overlying amphibolite is marked by a tectonic breccia up to $3 \mathrm{~m}$ thick (Leake et al. 1983).

The thrust sheet overlying the Delaney Dome Formation is composed of the basic Ballyconneely Amphibolite and interbanded quartz diorite and hornblende gneiss that intrude the Dalradian sediments (Tanner et al. 1989). Shear sense indicators within the fault zone show motion of the Dalradian and associated meta-gabbros toward the south over the Delaney Dome Formation and at a high angle to the earlier $\left(D_{2}\right)$ structures in the Dalradian (Leake et al. 1983; Tanner et al. 1989).
The geological origin of the Delaney Dome Formation and its significance to the Grampian Orogeny have long been in question, complicating attempts to restore the Connemara Dalradian to its pre-strike-slip location. The degree of mylonitization in the Delaney Dome Formation increases toward the Mannin Thrust, and this alteration has hindered previous attempts to correlate the original lithology of Delaney Dome Formation rocks with other formations.

It has been suggested that the Delaney Dome Formation shares lithologic characteristics with Ordovician volcanic rocks of the Tyrone Igneous Complex, and on that basis the Delaney Dome Formation has been correlated with the Midland Valley Terrane (Tanner et al. 1989). Leake \& Singh (1986) used major element whole rock chemistry to demonstrate a rhyolitic or granitic protolith for the Delaney Dome Formation, similar to the siliceous volcanic rocks of South Mayo. Alternatively, it has been suggested to correlate with post-collisional volcanic rocks above a south-facing continental arc following the Grampian Orogeny, such as those comprising the Southern Uplands Arc (Ryan \& Dewey 1991; Williams \& Rice 1989). In that scenario subduction polarity reversal is assumed to have played a part in forming the Delaney Dome rocks. Williams \& 
Rice (1989) suggested a similar origin for the Delaney Dome Formation and the Partry ignimbrites, a syn- to postcollisional unit of South Mayo (Graham et al. 1989).

\section{The age of the Delaney Dome Formation}

Previous age estimates of the Delaney Dome Formation have yielded widely variable results. These include an $\mathrm{Rb}-\mathrm{Sr}$ errorchron age of $460 \pm 25 \mathrm{Ma}$ for a geographically separated set of metarhyolite Delaney Dome Formation samples (Leake et al. 1983). Those data were reinterpreted by Kennan \& Murphy (1987), using a multiple errorchron technique to yield a mylonitization age of $426 \pm 10 \mathrm{Ma}$. Cliff et al. (1996) analysed a muscovite-bearing quartz vein from central Connemara, interpreted to have formed within deformation event $\mathrm{D}_{4}$, and obtained a $\mathrm{Rb}-\mathrm{Sr}$ muscovite-feldspar isochron age of $456 \pm 6 \mathrm{Ma}$. This implied an older age for the Delaney Dome Formation and syn- $\mathrm{D}_{3}$ Mannin Thrust. Even more restrictive evidence for an older Delaney Dome Formation age is provided by the $462 \mathrm{Ma}$ age of the Oughterard Granite (Friedrich et al. 1999b), which intrudes an $\mathrm{F}_{4}$ anticline that deforms the Mannin Thrust.

\section{Sampling and analysis}

In order to address the origin of the Delaney Dome Formation we have analysed the whole-rock trace and rare earth element composition of five Delaney Dome Formation samples taken along the shore in Mannin Bay (Fig. 1). We will also discuss previously unpublished $\mathrm{U}-\mathrm{Pb}$ dates of zircon grains from a mylonitic meta-rhyolite within the Delaney Dome Formation obtained by Friedrich (1998).

Two of the whole-rock Delaney Dome Formation samples were collected on the NW side of the Dome (ODD-1,2) and three are from the south side (ODD-3 to -5). Samples were powdered and dissolved prior to trace and rare earth element analysis by inductively coupled plasma-mass spectrometry at the Woods Hole Oceanographic Institution. Analytical uncertainties are $<2 \%$, determined by analysis of USGS standard BCR-2.

$\mathrm{U}-\mathrm{Pb}$ dating was performed by Friedrich (1998) on zircon crystals from a meta-rhyolite collected from the NW region of the Delaney Dome Formation (sample AF94-DD2). Zircons were air-abraded for 40 hours until all crystal faces were removed. $\mathrm{Pb}$ and $\mathrm{U}$ were isolated by $\mathrm{HCl}$-based anion exchange chromatography (Bowring et al. 1993; Krogh 1973). $\mathrm{U}-\mathrm{Pb}$ isotope analysis was performed by thermal ionization mass spectrometry at the Massachusetts Institute of Technology (Friedrich 1998).

\section{Results}

\section{Geochemistry}

The trace element characteristics of the Delaney Dome Formation can be rapidly assessed through use of a multi-element spider diagram (after Pearce 1982; fig. 2a). In this diagram elements are normalized against N-MORB values (Sun \& McDonough 1989) to assess the chemical contribution from subduction-related processes beyond normal melting of a depleted upper mantle source. The elements are arranged with water-mobile elements to the left of $\mathrm{Nb}$ and water-immobile elements on the right. Compatibility of elements in mantle
A
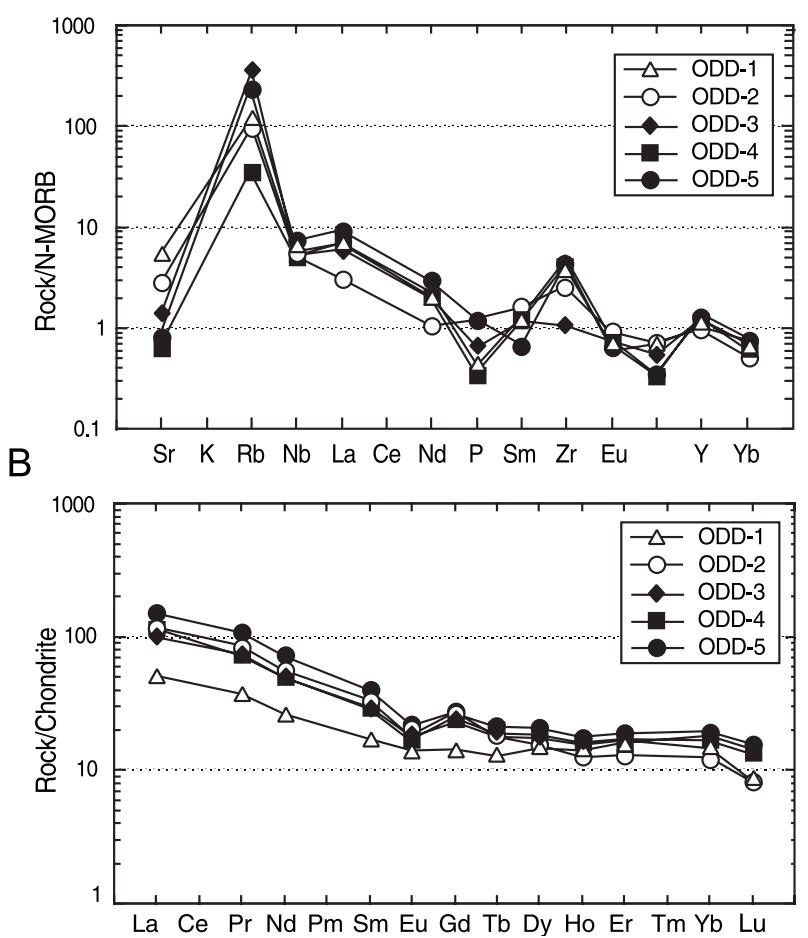

Fig. 2. (a) N-MORB normalized multi-element spider diagram (after Pearce, 1982) for samples of the Delaney Dome Formation.

(b) Chondrite-normalized rare earth element diagram of the Delaney Dome Formation.

phases increases left and right away from $\mathrm{Nb}$. Water-mobile elements may have been affected by burial alteration, but concentrations of water-immobile elements can be considered to be close to those originally in the volcanic rocks because metamorphic grade in the Delaney Dome Formation does not appear to be higher than greenschist. The Delaney Dome Formation shows a strong enrichment in most of the watermobile elements and an overall enriched pattern to the waterimmobile elements. A moderate relative $\mathrm{Nb}$ depletion is seen, together with stronger relative $\mathrm{P}$ and Ti depletions.

Figure $2 b$ shows the rare earth element (REE) character of the Delaney Dome Formation normalized against the chondrite values of Anders \& Grevesse (1989). The Delaney Dome Formation is clearly enriched in the light rare earth elements (LREE). Four of five Delaney Dome Formation samples show REE patterns with a slight negative $\mathrm{Eu}$ anomaly. Figure 3 shows La/Sm (a measure of LREE enrichment) plotted against $\mathrm{Nb} / \mathrm{Zr}$ (a measure of high field strength element enrichment) for the Delaney Dome Formation compared with volcanic rocks from the forearc strata preserved in the adjacent South Mayo Trough.

\section{$U-P b$ dating}

Three populations of zircon crystals were identifiable within mylonitic meta-rhyolites of the Delaney Dome Formation analysed by Friedrich (1998): clear, short crystals $(c .100 \mu \mathrm{m})$; cloudy, large crystals $(c .200 \mu \mathrm{m})$, and clear prismatic crystals (up to $160 \mu \mathrm{m}$ ). Zircon crystals from the two non-prismatic groups yielded discordant analyses with ${ }^{207} \mathrm{~Pb} /{ }^{206} \mathrm{~Pb}$ dates ranging from 992 to $1268 \mathrm{Ma}$ (Z4, Z7, Z8; Table 1). Five zircon crystals from the prismatic population are discordant 


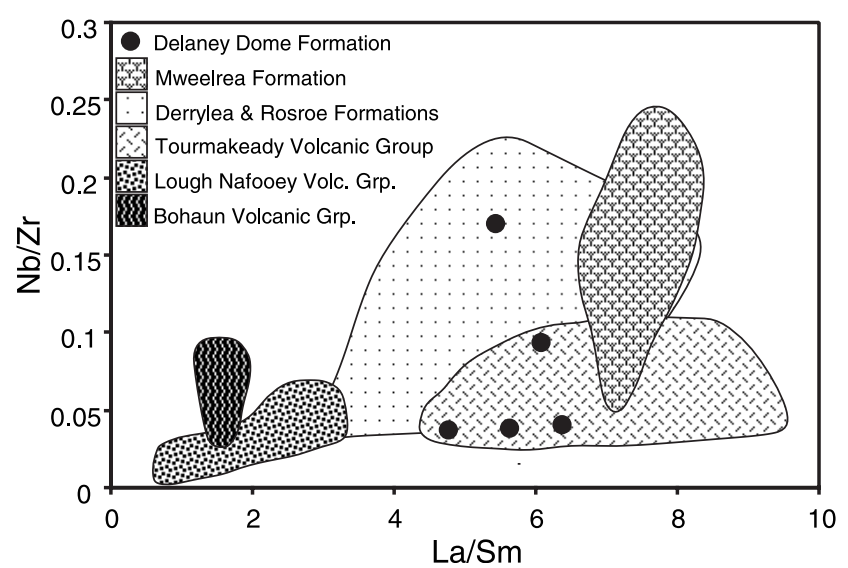

Fig. 3. $\mathrm{La} / \mathrm{Sm}$ v. $\mathrm{Nb} / \mathrm{Zr}$ ratio plot comparing the incompatible element composition of the Delaney Dome Formation to that of volcanic units in the South Mayo Trough (data from Clift \& Ryan 1994; Draut \& Clift 2001). Using these ratios the Delaney Dome Formation is shown to be similar to the Tourmakeady Volcanic Group and to the Derrylea and Rosroe Formations. Temporally the Delaney Dome Formation correlates with the Tourmakeady Volcanic Group and yields an older age than the Derrylea/Rosroe Formations.

and yield a weighted mean ${ }^{207} \mathrm{~Pb} /{ }^{206} \mathrm{~Pb}$ date of $475.9 \pm 2.2 \mathrm{Ma}$ (Z5, Z9, Z10, Z11, Z12; Table 1). A linear regression through these five analyses of prismatic zircons yields an upper intercept age of $474.6 \pm 5.5 \mathrm{Ma}$ (Fig. 4; Friedrich 1998).

\section{Interpretation}

\section{Geochemistry}

The general form of the Delaney Dome Formation spider diagrams (Fig. 2a) is consistent with the generation of these rocks within a continental subduction zone setting. The enriched trace and LREE character (Fig. 2) is typical of continental arcs (e.g., Andes; Pearce 1982) and contrasts with the flat patterns on spider diagrams of oceanic arcs (Ewart \& Hawkesworth 1987), including the basaltic Lough Nafooey Group of South Mayo (Clift \& Ryan 1994). The slight relative $\mathrm{Nb}$ depletion apparent in Figure 2a is characteristic of arc magmatism (e.g. Ryerson \& Watson 1987; Davidson 1996). Relative depletions in $\mathrm{P}$ and Ti probably reflect removal of apatite and $\mathrm{Ti} / \mathrm{Fe}$ oxides during fractional crystallization, consistent with the evolved high-silica major element composition (Watson \& Capobianco 1981). The LREE enrichment and high field strength element content of Delaney Dome Formation samples indicated in Figure 3 demonstrate clear differences between the Delaney Dome Formation and primitive South Mayo units such as the oceanic basalts of the Lough Nafooey Volcanic Group. Excepting one outlying sample, the element ratios in Figure 3 show similarity between the Delaney Dome Formation and the more evolved Tourmakeady Volcanic Group of South Mayo.

\section{Geochronology}

The discordant 992-1268 Ma ages from the clear, short zircon crystals and the cloudy, large crystals are interpreted to have been derived from a crustal source that predated the collisional magmatism (Friedrich 1998), i.e., they are xenocrystic zircons assimilated from Laurentian country rock. The age of Delaney
Dome Formation volcanism is derived from the upper intercept of the linear regression through the five analyses of discordant prismatic zircons (shown in Figure 4), and is thus estimated as $474.6 \pm 5.5 \mathrm{Ma}$ (Friedrich 1998).

\section{Discussion}

In an attempt to understand the place of the Delaney Dome Formation in the magmatic evolution of the Laurentian margin we attempt to correlate this unit with stratigraphic elements of the adjacent South Mayo Trough terrane, where chemical evolution during the Grampian Orogeny has been well documented (Ryan et al. 1980; Clift \& Ryan 1994; Draut $\&$ Clift 2001). Trace and rare earth element data are particularly valuable tools of stratigraphic correlation when used in conjunction with lithology, major element composition, and geochronology. We employ a matrix of all of the above lines of evidence to demonstrate a close comparison between the Delaney Dome Formation and the Tourmakeady Volcanic Group of the South Mayo Trough.

The new $\mathrm{U}-\mathrm{Pb}$ age of $474.6 \pm 5.5 \mathrm{Ma}$ for the Delaney Dome Formation correlates well with the Arenig biostratigraphic age of the Tourmakeady Volcanic Group (e.g. Graham et al. 1989), using the most recent time scale established for Ordovician stratigraphy (Tucker \& McKerrow 1995). The age of the Tourmakeady Volcanic Group is assumed to span $c$. 482-470 Ma based on that time scale and the well-documented graptolite record of South Mayo. No other stratigraphic units of South Mayo are believed to lie within that age range.

The enrichment of incompatible trace elements in the MORB-normalized spider diagram, the pronounced LREE enrichment shown in Figure $2 \mathrm{~b}$, and the relative $\mathrm{Nb}$ depletion indicative of arc magmatism (Fig. 2a) are all characteristics shared with the Tourmakeady Volcanic Group of South Mayo (Draut \& Clift 2001). Additionally, Leake \& Singh (1986) demonstrated a rhyolitic or granitic protolith for the Delaney Dome Formation based upon a detailed analysis of its major element composition that agrees well with the highly siliceous character of the Tourmakeady Volcanic Group. Tuff and rhyolite samples from the Tourmakeady Volcanic Group display $70 \%$ silica content (Clift \& Ryan 1994), similar to that of the Delaney Dome Formation at $73 \%$ (Leake \& Singh 1986).

These characteristics are all consistent with the theory that, like the Tourmakeady Volcanic Group, the rhyolites that comprise the Delaney Dome Formation protolith were erupted during the arc-continent collision of the Grampian Orogeny (Draut \& Clift 2001). A comparison of incompatible element ratios (Fig. 3) clearly shows that the trace element character of the Delaney Dome Formation is quite distinct from the more depleted compositions of the Lough Nafooey Volcanic Group in South Mayo, the eruption of which preceded arc-continent collision (Ryan et al. 1980; Clift \& Ryan 1994). Although the trace element character of the Delaney Dome Formation is not unlike that of the more enriched volcanic rocks of the Rosroe and stratigraphically equivalent Derrylea Formation that succeed the Tourmakeady Volcanic Group within the South Mayo Trough (Fig. 3), the chemical composition of the Delaney Dome Formation best correlates with that of the Tourmakeady Group, and that also provides the best age and lithologic correlation. The overall similarity in composition, and in age, between samples from the Delaney Dome 


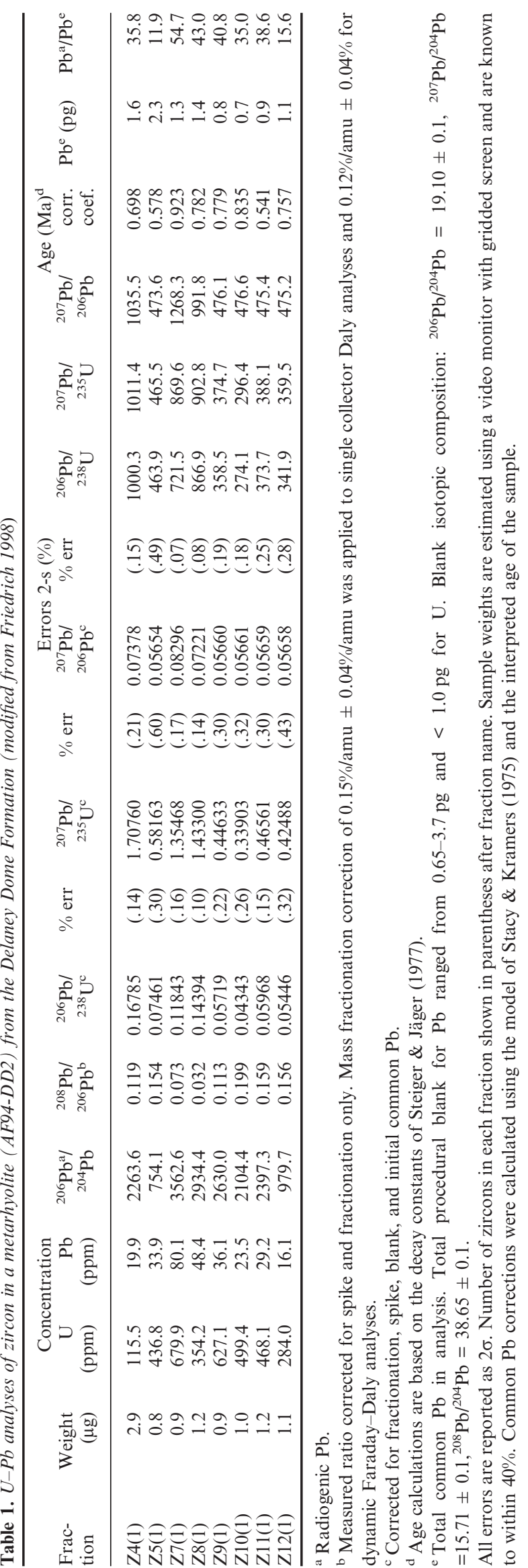




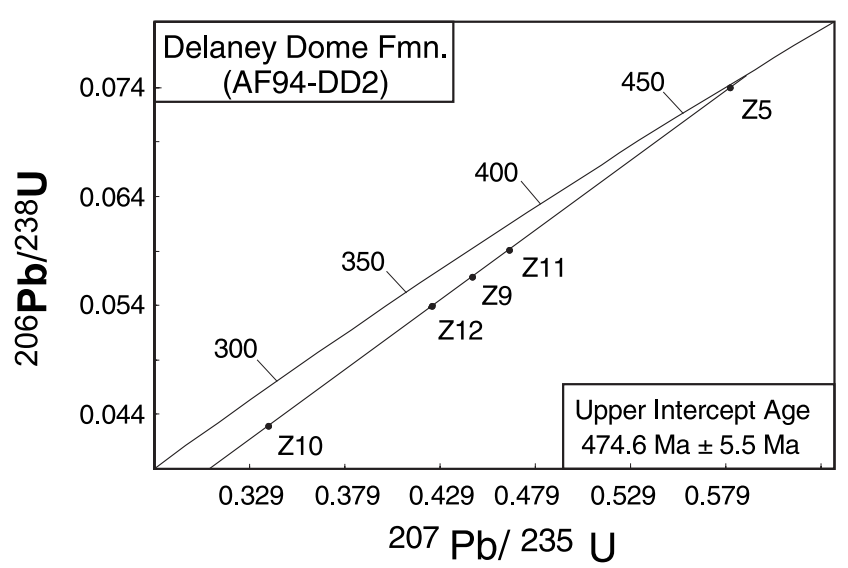

Fig. 4. U-Pb concordia diagram for five prismatic zircon crystals from a metarhyolite of the Delaney Dome Formation (Sample AF94-DD2; Friedrich 1998).

Formation and Tourmakeady Volcanic Group of South Mayo strongly suggests that the Delaney Dome is a part of the syn-collisional arc volcanic sequence preserved in the South Mayo Trough that has since been underthrust by Dalradian rocks and their associated mafic intrusions.

\section{Eruption and emplacement of the Delaney Dome Formation}

The similarities in age, lithology, and trace element composition between the Delaney Dome Formation and an Ordovician arc volcanic unit such as the Tourmakeady Volcanic Group imply that the Delaney Dome Formation originated in a syn-collisional arc setting. The Delaney Dome Formation therefore has a distinctly different parentage from the metamorphosed continental margin sediments and intracratonic basin deposits that comprise most of Connemara. Despite being approximately equivalent in age to the Delaney Dome Formation (Friedrich et al. 1999b), intrusions within the Connemara Dalradian are dominantly mafic and coarser grained. The finer grained character of the Delaney Dome Formation (Leake \& Singh 1986) supports the chemical implication of a meta-extrusive origin. We believe that the Delaney Dome Formation represents a fragment of the evolved upper crust of the syn-collisional arc, while the gabbroic intrusions within the Connemara Dalradian represent the exhumed middle crust of that same arc. The Delaney Dome Formation is therefore an extrusive temporal equivalent of intrusions that penetrate the Connemara Dalradian. Thus, movement along the Mannin Thrust brought mid-crustal plutons and Dalradian country rocks tectonically above the extrusive volcanic sequence, emplacing the mid-crust of the arc over its extrusive upper crust. In this scenario, as postulated by Friedrich (1998), the Mannin Thrust represents a major structure imbricating a syn-collisional arc but does not represent a boundary between two exotic terranes, as does the boundary between South Mayo and Connemara. The motion on the boundary between the South Mayo Trough and the imbricated Connemara Dalradian/Delaney Dome Formation apparently postdates all motion on the Mannin Thrust.

Figure 5 shows a tectonic model for eruption and emplacement of the Delaney Dome Formation within the context of the western Irish Caledonides. Previous work has demonstrated that the Lough Nafooey arc began as an intraoceanic arc (Ryan et al. 1980; Clift \& Ryan 1994) and collided with the Laurentian continent prior to the Silurian final suturing of Iapetus (e.g. McKerrow et al. 1991; van Staal et al. 1998). The Laurentian margin was passive prior to collision, but subsequently developed as a SE-facing continental arc due to a reversal in subduction polarity following the Grampian Orogeny (e.g. Dewey \& Ryan 1990). By approximately $478 \mathrm{Ma}$, as the Lower Tourmakeady Volcanic Group was erupted in South Mayo, the Lough Nafooey Arc had collided with the continental margin. Dalradian passive margin sediments had undergone extensive metamorphism during the collision. Continental material was incorporated into the volcanic material (Draut \& Clift 2001), supporting the assumption of advanced collision and arc-continent suturing by this stage. During eruption of the Upper Tourmakeady Group (until approximately $472 \mathrm{Ma}$ ) and Delaney Dome rhyolites, mafic intrusions penetrated the Dalradian country rock (e.g. Friedrich et al. 1999a, b). The reversal in subduction polarity and establishment of a continental arc that followed the Grampian Orogeny had begun.

Following the eruption of rhyolites that comprise the Tourmakeady Volcanic Group and Delaney Dome Formation protolith, continued compression thrust Dalradian rocks and associated mafic intrusions over a section of the syn-collisional volcanics along the Mannin Thrust, separating the Tourmakeady Volcanic Group and other South Mayo units from the Delaney Dome Formation protolith and causing mylonitization of the Delaney Dome Formation rhyolites along the thrust zone. At the same time, metamorphic cooling rates derived from $\mathrm{U}-\mathrm{Pb}$ ages and ${ }^{40} \mathrm{Ar} /{ }^{39} \mathrm{Ar}$ data (Friedrich et al. $1999 a, b)$ indicate rapid cooling of mafic intrusions within Connemara. Exhumation of the arc core by uplift and extensional faulting has been proposed as a mechanism by which rapid cooling of an orogen could be explained (e.g. Sonder et al. 1987; Herren 1987). Such rapid cooling rates (minimum $35^{\circ} \mathrm{C} \mathrm{Ma}^{-1}$ from $468-460 \mathrm{Ma}$; Friedrich et al. 1999b) could have been accomplished by extension along an east-westtrending tectonic discontinuity through northern Connemara known as the Renvyle-Bofin Slide, as proposed by Wellings (1998), and/or on low-angle extensional faults south of Connemara (Williams \& Rice 1989). Uplift and extension must have been synchronous with motion on the Mannin Thrust to allow the metamorphic complexes in the hanging wall of the thrust to be extruded from depth and subsequently exposed. This model of uplift and extension in the latter stages of arc-continent collision and orogenesis parallels that of largerscale continent-continent collisions such as that which produced the Himalayas; we suggest that synchronous extension and compression in the Irish Caledonides resembles the synchronous activity of the Himalaya Main Central Thrust and the major Zanskar and South Tibetan detachments (Herren 1987; Burchfiel et al. 1992; Hodges et al. 1992; Edwards \& Harrison 1997).

By the time of eruption of the Rosroe and Mweelrea tuffs in South Mayo, around 460 Ma (e.g. Draut \& Clift 2001), a new subduction zone had developed in which a North-dipping slab descended below a continental arc (Dewey \& Ryan 1990). Late in Grampian history, strike-slip faulting emplaced the Connemara metamorphic terrane next to the South Mayo volcanic and sedimentary sequences. The exact timing of this strike-slip motion has not been well-constrained, but is typically considered to be Late Llanvirn to Caradoc (c. 460 to $>443 \mathrm{Ma}$ ) based on the approximate age of the Derryveeny 
A

$478 \mathrm{Ma}$ (Lower Tourmakeady Formation)

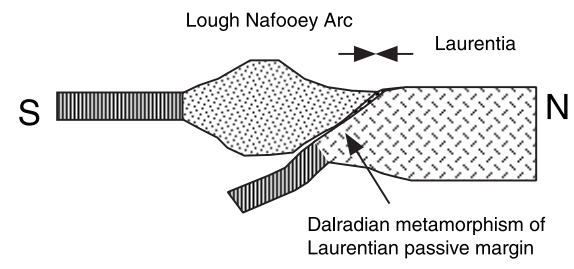

B

472 Ma (Upper Tourmakeady Formation)

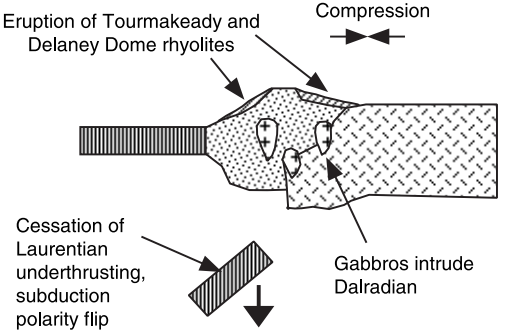

C

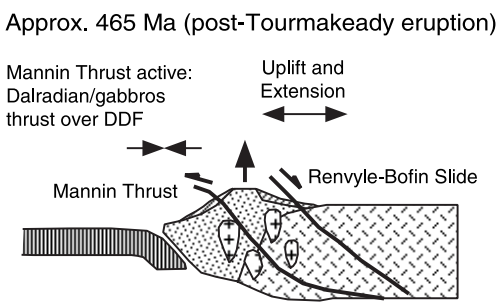

D $460 \mathrm{Ma}$ (Rosroe and Mweelrea Formations)

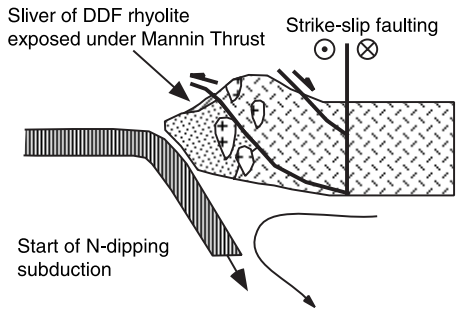

Fig. 5. Cross-sectional images showing the proposed tectonic model for eruption of the Delaney Dome rhyolites and emplacement in the context of the present-day suture zone in western Ireland. In all diagrams North is to the right, south to the left. (a) At approximately 478 Ma, during the time of eruption of the Lower Tourmakeady Group in South Mayo, the Lough Nafooey Arc had collided with Laurentia following the closure of a south-dipping subduction zone. Metamorphism of Dalradian passive margin sediments had occurred. (b) By 472 Ma, the Upper Tourmakeady Group and Delaney Dome rhyolites had been erupted, incorporating Laurentian continental material into their composition. Mafic intrusions penetrated the Dalradian country rock. Subduction polarity reversal that followed the Grampian Orogeny had begun. (c) By approximately $465 \mathrm{Ma}$, continued compression caused movement of a thrust sheet containing Dalradian and mafic intrusions over part of the rhyolites erupted during orogeny, separating Delaney Dome Formation protolith from Tourmakeady Volcanic Group volcanics and causing mylonitization of the Delaney Dome Formation. The orogen underwent rapid uplift as inferred from metamorphic cooling rates, and associated extension (probably along the Renvyle-Bofin slide) that exposed the metamorphic complexes present in the hanging wall of the Mannin Thrust. (d) By $460 \mathrm{Ma}$, evidence of resumed subduction is apparent in the chemical signal of the Rosroe and Mweelrea tuffs in South Mayo. The newly subducting slab dipped to the north. Late in Grampian history, strike-slip faulting emplaced the Connemara metamorphic terrane next to the South Mayo volcanic and sedimentary sequences.

Conglomerate in South Mayo, which contains clasts of Connemara-type lithologies derived from the south (Graham et al. 1991).

\section{Additional correlations within the Appalachian/ Caledonide Orogen}

The Grampian extrusive volcanic sequence represented by the Delaney Dome Formation and South Mayo Trough units such as the Tourmakeady Volcanic Group is not extensively preserved in the Iapetus suture zone of the British Isles. Additional along-strike equivalents of these syn-collisional arc volcanic units have likely been subject to overthrusting and burial, in a similar manner to the overthrusting of the Delaney Dome Formation, during the Grampian Orogeny and the Silurian final closure of Iapetus. The Tyrone Igneous Complex of Ireland does contain Ordovician volcanic rocks which, although they have been suggested to correlate with the Delaney Dome Formation (Tanner et al. 1989), apparently postdate the Delaney Dome Formation/Tourmakeady Volcanic Group rhyolitic eruptions and yield Llandeilo-Caradoc ages (Hutton et al. 1985).

Although later deformation and burial preclude confident correlation of the Delaney Dome Formation/Tourmakeady Volcanic Group volcanics with other units in the British Isles, additional correlative units may exist within the North American continuation of the Iapetus suture zone, where
Grampian/Taconic volcanic units are present (e.g. Dunning et al. 1987; Swinden et al. 1997; Karabinos et al. 1998). In particular, Newfoundland sequences that comprise the northeastern end of the Appalachian orogenic belt contain ArenigLlanvirn arc volcanic rocks that are likely related to the syn-collisional volcanic sequence of western Ireland (see Swinden et al. 1997 for detailed review of Ordovician units in Newfoundland). A series of Late Cambrian to Early Ordovician arc volcanic rocks are preserved within Newfoundland's Notre Dame subzone, including boninites, island arc tholeiites, calc-alkalic basalt and andesite, and felsic volcanic units. These are considered to have formed within island arcs and back-arc basins in the Iapetus Ocean (e.g. Jenner \& Fryer 1980; Coish et al. 1982; Swinden et al. 1997; Whalen et al. 1997; van Staal et al. 1998), although their spatial relationships within Iapetus are difficult to constrain (Swinden et al. 1997). Among this volcanic series, the felsic Buchan Group and Robert's Arm Group (Strong 1977) in particular display very similar traits to the Delaney Dome Formation and Tourmakeady Volcanic Group.

The $150 \mathrm{~km}$ long Buchan-Robert's Arm volcanic belt, located within the Notre Dame subzone, contains basaltic and rhyolitic volcanic sequences that yield Arenig to early Llanvirn biostratigraphic ages (Nowlan \& Thurlow 1984). This volcanic belt is bounded to the west by faults that juxtapose the volcanic sequences against the Arenig Eastern Ophiolite Belt, and to the east by the major Red Indian Line suture, which 
separates the Notre Dame and Exploits subzones of the northeastern Appalachians (e.g. van Staal et al. 1998). Trace element analyses of the Buchan and Robert's Arm Groups reveal uniform LREE enrichment and strong relative $\mathrm{Nb}$ depletion, implying formation in a continental volcanic arc setting (Swinden et al. 1997). $\varepsilon_{\mathrm{Nd}(\mathrm{t})}$ values of -10 have been obtained for rhyolites in the Buchan and Robert's Arm Groups (Swinden et al. 1997). While no Nd data are available for Delaney Dome Formation samples, the negative values for the Buchan and Robert's Arm Groups are similar to $\varepsilon_{\mathrm{Nd}(\mathrm{t})}$ values of -12 and -14 obtained for the Tourmakeady Volcanic Group (Draut \& Clift 2001). Such pronounced negative $\varepsilon_{\mathrm{Nd}(\mathrm{t})}$ indicates substantial involvement of continental material in arc petrogenesis for both the Tourmakeady Volcanic Group and Buchan-Robert's Arm Groups.

$\mathrm{U}-\mathrm{Pb}$ analyses of zircon grains from the Buchan and Robert's Arm Groups have yielded ages of $473 \mathrm{Ma}$ and $473 \pm 2$ Ma respectively (Dunning et al. 1987), in excellent agreement with the $\mathrm{U}-\mathrm{Pb}$ age of $474.6 \pm 5.5 \mathrm{Ma}$ for the Delaney Dome Formation discussed herein. Some age disparity is to be expected between eruption of volcanic units of similar origin in Ireland and the northern Appalachians given the diachronous nature of the Grampian Orogeny along strike (van Staal et al. 1998). However this close temporal association between eruption of highly evolved arc rhyolites with a continental component in western Ireland and in Newfoundland, together with the similarity in trace and major element composition and $\mathrm{Nd}$ isotope chemistry of these rhyolites, suggests that a correlation may be established not only between the Tourmakeady Volcanic Group and Delaney Dome Formation of western Ireland but also between these units and the Buchan-Robert's Arm volcanic belt in the North American continuation of the Appalachian-Caledonide orogen.

\section{Conclusions}

Multiple lines of chemical, lithologic, and geochronologic evidence point to a correlation between the Delaney Dome Formation of Connemara and the Tourmakeady Volcanic Group of South Mayo. This implies a syn-collisional volcanic arc origin for the Delaney Dome meta-rhyolites. The magmatism that accompanied arc-continent collision during the Grampian Orogeny preserved in western Ireland is manifest as mid-crustal plutons within the Dalradian meta-sediments and as rhyolitic volcanic rocks in the Delaney Dome Formation and their lateral equivalents in the Tourmakeady Volcanic Group of South Mayo. Toward the end of the Grampian Orogeny, mid-crustal plutons and Dalradian country rock were thrust toward the SW over these rhyolites along the Mannin Thrust, resulting in the tectonic window into the Delaney Dome Formation now exposed. This represents a major imbrication of the syn-collisional arc, emplacing the mid-crust of the arc over its extrusive upper crust. The Mannin Thrust is thus interpreted as a major intra-arc structure but not a terrane boundary. The recognition of such intra-arc thrusting is of tectonic significance to interpretation of similar collision zones elsewhere and to an understanding of the general processes of arc-continent collision. We suggest a correlation not only between the Tourmakeady Volcanic Group and Delaney Dome Formation of western Ireland but also between these units and felsic arc volcanic rocks in the northern Appalachians of Newfoundland.
The authors wish to thank Anke Friedrich for graciously providing a figure and data from her doctoral thesis. Lary Ball at WHOI assisted with ICP-MS analyses; Mark Martin at MIT assisted with U-Pb analyses. Anke Friedrich, Chris Hepburn, Cees van Staal, Paul Ryan, Paddy Orr and Mike Williams are thanked for their practical advice and stimulating discussion. The paper was improved by comments from C. Mac Niocaill, S. Turner, and an anonymous reviewer. This is Woods Hole Oceanographic Institution contribution number 10546.

\section{References}

Anders, E. \& Grevesse, N. 1989. Abundances of the elements: Meteoritic and solar. Geochimica et Cosmochimica Acta, 53, 197-214.

Bluck, B.J. \& Dempster, T.J. 1991. Exotic metamorphic terranes in the Caledonides: Tectonic history of the Dalradian Block, Scotland. Geology, 19, 1133-1136.

Bowring, S.A., Grotzinger, J.P., Isachsen, C.E., Knoll, A.H., Pelechaty, S.M. \& Kolosov, P. 1993. Calibrating rates of early Cambrian evolution. Science, 261, 293-1298.

Burchfiel, B.C., Chen, Z., Hodges, K.V., Liu, Y., Royden, L.H., Deng, C. \& Xu, J. 1992. The South Tibetan Detachment System, Himalayan Orogen: Extension Contemporaneous With and Parallel to Shortening in a Collisional Mountain Belt. Geological Society of America Special Paper, 269.

Cliff, R.A., Yardley, B.W.D. \& Bussy, F. 1996. U-Pb and Rb-Sr geochronology of magmatism and metamorphism in the Dalradian of Connemara, W. Ireland. Journal of the Geological Society, London, 153, 109-120.

Clift, P.D. \& RyAN, P.D. 1994. Geochemical evolution of an Ordovician island arc, South Mayo, Ireland. Journal of the Geological Society, London, 151, 329-342.

Coish, R.A., Hickey, R. \& Frey, F.A. 1982. Rare earth element geochemistry of the Betts Cove ophiolite, Newfoundland: complexities in ophiolite formation. Geochimica et Cosmochimica Acta, 46, 2117-2134.

Davidson, J.P. 1996. Deciphering Mantle and Crustal Signatures in Subduction Zone Magmatism. In: Bebout, G.E., Scholl, D.W., Kirby, S.H. \& Platt, J.P. (eds) Subduction top to bottom. AGU Geophysical Monograph, 96, 251-262.

Dewey, J.F. \& Ryan, P.D. 1990. The Ordovician Evolution of the South Mayo Trough, western Ireland. Tectonics, 9, 887-901.

Draut, A.E. \& Clift, P.D. 2001. Geochemical evolution of arc magmatism during arc-continent collision, South Mayo, Ireland. Geology, 29, 543-546.

Dunning, G.R., Kean, B.F., Thurlow, J.G. \& Swinden, H.S. 1987. Geochronology of the Buchans, Robert's Arm and Victoria Lake Groups and the Mansfield Cove Complex, Newfoundland. Canadian Journal of Earth Sciences, 24, 1175-1184.

Edwards, M.A. \& Harrison, T.M. 1997. When did the roof collapse? Late Miocene north-south extension in the high Himalaya revealed by $\mathrm{Th}-\mathrm{Pb}$ monazite dating of the Khula Kangri granite. Geology, 25, 543-546.

Ewart, A. \& Hawkesworth, C.J. 1987. The Pleistocene-recent TongaKermadec Arc lavas; interpretation of new isotopic and rare earth data in terms of a depleted mantle source model. Journal of Petrology, 28, 495-530.

Friedrich, A.M. 1998. ${ }^{40} \mathrm{Ar}{ }^{39} \mathrm{Ar}$ and $\mathrm{U}-\mathrm{Pb}$ Geochronological constraints on the thermal and tectonic evolution of the Connemara Caledonides, Western Ireland. Doctoral Thesis, Department of Earth, Atmospheric, and Planetary Sciences, Massachusetts Institute of Technology.

Friedrich, A.M., Bowring, S.A., Martin, M.W. \& Hodges, K.V. 1999a. Short-lived continental magmatic arc at Connemara, western Irish Caledonides: Implications for the age of the Grampian orogeny. Geology, 27, $27-30$.

Friedrich, A.M., Hodges, K.V., Bowring, S.A. \& Martin, M.W. 1999b. Geochronological constraints on the magmatic, metamorphic, and thermal evolution of the Connemara Caledonides, western Ireland. Journal of the Geological Society, London, 156, 1217-1230.

Graham, J.R., Leake, B.E. \& Ryan, P.D. 1989. The Geology of South Mayo, western Ireland. Publication of the Department of Geology and Applied Geology, University of Glasgow.

Graham, J.R., Wrafter, J.P., Daly, J.S. \& Menuge, J.F. 1991. A local source for the Ordovician Derryveeny Conglomerate Formation, western Ireland: implications for the Connemara Dalradian. In: Morton, A.C., TodD, S.P. \& Haughton, P.D.W. (eds) Developments in Sedimentary Provenance Studies. Geological Society, London, Special Publications, 57, 199-233.

Harris, A.L., Haselock, P.J., Kennedy, M.J., Mendum, J.R., Long, C.B., Winchester, J.A. \& Tanner, P.W.G. 1994. The Dalradian Supergroup in Scotland, Shetland and Ireland. In: Gibbons, W. \& Harris, A.L. (eds) $A$ revised correlation of Precambrian rocks in the British Isles. Geological Society, London, Special Reports, 22, 33-53.

Herren, E. 1987. Zanskar shear zone; NE-SW extension within the Higher Himalayas (Ladakh, India). Geology, 15, 409-413.

Hodges, K.V., Parrish, R.R., Housh, T.B., Lux, D.R., Burchfiel, B.C., Royden, L.H. \& Chen, Z. 1992. Simultaneous Miocene extension and shortening in the Himalayan Orogen. Science, 258, 1466-1470. 
Hutton, D.H.W. 1987. Strike-slip terranes and a model for the evolution of the British and Irish Caledonides. Geological Magazine, 124, 405-425.

Hutton, D.H.W., Aftalion, M. \& Halliday, A.N. 1985. An Ordovician ophiolite in County Tyrone, Ireland. Nature, 315, 210-212.

Jenner, G.A. \& Fryer, B.J. 1980. Geochemistry of the upper Snooks Arm Group basalts, Burlington Peninsula, Newfoundland: Evidence against formation in an island arc. Canadian Journal of Earth Sciences, 17, 888-900.

Karabinos, P., Samson, S.D., Hepburn, J.C. \& Stoll, H.M. 1998. Taconian Orogeny in the New England Appalachians; collision between Laurentia and the Shelburne Falls Arc. Geology, 26, 215-218.

Kennan, P.S. \& Murphy, F.C. 1987. Tectonically reset Rb-Sr system during late Ordovician terrane assembly in Iapetus, western Ireland. Geology, 15, $1155-1158$

KroGH, T.E. 1973. A low-contamination method for hydrothermal decomposition of zircon and extraction of $\mathrm{U}$ and $\mathrm{Pb}$ for isotopic age determination. Geochimica et Cosmochimica Acta, 37, 485-494.

LEAKE, B.E. 1986. The geology of SW Connemara, Ireland; a fold and thrust Dalradian and metagabbroic-gneiss complex. Journal of the Geological Society of London, 143, 221-236.

Leake, B.E. \& Singh, D. 1986. The Delaney Dome Formation, Connemara, W. Ireland, and the geochemical distinction between ortho- and paraquartzofeldspathic rocks. Mineralogical Magazine, 50, 205-215.

Leake, B.E., Tanner, P.W.G., Singh, D. \& Halliday, A.N. 1983. Major southward thrusting of the Dalradian rocks of Connemara, western Ireland. Nature, 305, 210-213.

McKerrow, W.S., Dewey, J.F. \& Scotese, C.R. 1991. The Ordovician and Silurian development of the Iapetus Ocean. Special Papers in Palaeontology, 44, 165-178.

Nowlan, G.S. \& Thurlow, J.G. 1984. Middle Ordovician conodonts from the Buchans Group, central Newfoundland, and their significance for regional stratigraphy of the Central Volcanic Belt. Canadian Journal of Earth Sciences, 21, 284-296.

Pearce, J.A. 1982. Trace element characteristics of lavas from destructive plate boundaries. In: THORPE, R.S. (ed.) Andesites. John Wiley, Chichester, $525-543$.

Ryan, P.D. \& Dewey, J.F. 1991. A geological and tectonic cross-section of the Caledonides of western Ireland. Journal of the Geological Society, London, 148, 173-180

Ryan, P.D., Floyd, P.A. \& ArCher, J.B. 1980. The stratigraphy and petrochemistry of the Lough Nafooey Group (Tremadocian), western Ireland. Journal of the Geological Society, London, 137, 443-458.

RYERSON, F.J. \& WATSON, E.B. 1987. Rutile saturation in magmas: implications for Ti-Nb-Ta depletion in island-arc basalts. Earth and Planetary Science Letters, 86, 225-239.

Sonder, L.J., England, P.C., Wernicke, B.P. \& Christiansen, R.L. 1987. A physical model for Cenozoic extension of western North America. In: Coward, M.P., Dewey, J.F. \& Hancock, P.L. (eds) Continental Extensional Tectonics. Geological Society, London, Special Publications, 28, 187-201.
Soper, N.J., Ryan, P.D. \& Dewey, J.F. 1999. Age of the Grampian Orogeny in Scotland and Ireland. Journal of the Geological Society, London, 156, 1231-1236.

Stacey, J.S. \& Kramers, J.D. 1975. Approximation of terrestrial lead isotope evolution by a two stage model. Earth and Planetary Science Letters, 26, 207-221.

STEIGER, R.H. \& JÄGER, E. 1977. Subcommission on geochronology: convention on the use of decay constants in geo- and cosmochronology. Earth and Planetary Science Letters, 60, 359-362.

Strong, D.F. 1977. Volcanic regimes of the Newfoundland Appalachians. In: Baragar, W.R.A., Coleman, L.C. \& Hall, J.M. (eds) Volcanic regimes in Canada. Geological Association of Canada Special Papers, 16, 61-90.

Sun, S.-S. \& MCDonough, W.F. 1989. Chemical and isotopic systematics of oceanic basalts: implications for mantle compostion and processes. In: SAunders, A.D. \& Norry, M.J. (eds). Magmatism in the Ocean Basins. Geological Society, London, Special Publications, 42, 313-345.

Swinden, H.S., Jenner, G.A. \& Szybinski, Z.A. 1997. Magmatic and tectonic evolution of the Cambrian-Ordovician Laurentian margin of Iapetus: Geochemical and isotopic constraints from the Notre Dame subzone, Newfoundland. Geological Society of America Memoir, 191, 337-365.

Tanner, P.W.G., Dempster, T.J. \& Dickin, A.P. 1989. Time of docking of the Connemara terrane with the Delaney Dome Formation, western Ireland. Journal of the Geological Society, London, 146, 389-392.

Tucker, R.D. \& MCKerrow, W.S. 1995. Early Paleozoic chronology: a review in light of new U-Pb zircon ages from Newfoundland and Britain. Canadian Journal of Earth Sciences, 32, 368-379.

van Staal, C.R., Dewey, J.F., Mac Niociall, C. \& McKerrow, W.S. 1998. The Cambrian-Silurian tectonic evolution of the northern Appalachians and British Caledonides: history of a complex, west and southwest Pacifictype segment of Iapetus. In: BLundell, D.J. \& ScotT, A.C. (eds) Lyell: the Past is the Key to the Present. Geological Society, London, Special Publications, 143, 198-242.

Watson, E.B. \& CAPOBIAnCO, C.J. 1981. Phosphorous and the rare earth elements in felsic magmas: an assessment of the role of apatite. Geochimica et Cosmochimica Acta, 45, 2349-2358.

Wellings, S.A. 1998. Timing of deformation associated with the syn-tectonic Dawros-Currywongaun-Doughruagh Complex, NW Connemara, western Ireland. Journal of the Geological Society of London, 155, 23-25.

Whalen, J.B., Jenner, G.A., Longstaffe, F.J., Gariepy, C. \& Fryer, B.J. 1997. Implications of granitoid geochemical and isotopic $(\mathrm{Nd}, \mathrm{O}, \mathrm{Pb})$ data from the Cambrian-Ordovician Notre Dame arc for the evolution of the Central Mobile belt, Newfoundland Appalachians. Geological Society of America Memoir, 191, 367-395.

Williams, D.M. \& Rice, A.H.N. 1989. Low-angle extensional faulting and the emplacement of the Connemara Dalradian, Ireland. Tectonics, 8 , $427-428$.

YARDLEY, B.W.D. 1976. Deformation and metamorphism of Dalradian rocks and evolution of the Connemara Cordillera. Journal of the Geological Society, London, 132, 521-542. 